University of Montana

ScholarWorks at University of Montana

Ecosystem and Conservation Sciences Faculty

Publications

Ecosystem and Conservation Sciences

2011

\title{
Climate-Mediated Nitrogen and Carbon Dynamics in a Tropical Watershed
}

Ashley P. Ballantyne

University of Montana - Missoula, ashley.ballantyne@umontana.edu

P. A. Baker

S. C. Fritz

B. Poulter

Follow this and additional works at: https://scholarworks.umt.edu/decs_pubs

Part of the Biogeochemistry Commons

Let us know how access to this document benefits you.

\section{Recommended Citation}

Ballantyne, Ashley P.; Baker, P. A.; Fritz, S. C.; and Poulter, B., "Climate-Mediated Nitrogen and Carbon Dynamics in a Tropical Watershed" (2011). Ecosystem and Conservation Sciences Faculty Publications. 2. https://scholarworks.umt.edu/decs_pubs/2

This Article is brought to you for free and open access by the Ecosystem and Conservation Sciences at ScholarWorks at University of Montana. It has been accepted for inclusion in Ecosystem and Conservation Sciences Faculty Publications by an authorized administrator of ScholarWorks at University of Montana. For more information, please contact scholarworks@mso.umt.edu. 


\title{
Climate-mediated nitrogen and carbon dynamics in a tropical watershed
}

\author{
A. P. Ballantyne, ${ }^{1,2}$ P. A. Baker, ${ }^{1}$ S. C. Fritz, ${ }^{3}$ and B. Poulter ${ }^{1,4}$ \\ Received 27 July 2010; revised 3 December 2010; accepted 2 February 2011; published 18 May 2011.
}

[1] Climate variability affects the capacity of the biosphere to assimilate and store important elements, such as nitrogen and carbon. Here we present biogeochemical evidence from the sediments of tropical Lake Titicaca indicating that large hydrologic changes in response to global glacial cycles during the Quaternary were accompanied by major shifts in ecosystem state. During prolonged glacial intervals, lake level was high and the lake was in a stable nitrogen-limited state. In contrast, during warm dry interglacials lake level fell and rates of nitrogen concentrations increased by a factor of 4-12, resulting in a fivefold to 24-fold increase in organic carbon concentrations in the sediments due to increased primary productivity. Observed periods of increased primary productivity were also associated with an apparent increase in denitrification. However, the net accumulation of nitrogen during interglacial intervals indicates that increased nitrogen supply exceeded nitrogen losses due to denitrification, thereby causing increases in primary productivity. Although primary productivity in tropical ecosystems, especially freshwater ecosystems, tends to be nitrogen limited, our results indicate that climate variability may lead to changes in nitrogen availability and thus changes in primary productivity. Therefore some tropical ecosystems may shift between a stable state of nitrogen limitation and a stable state of nitrogen saturation in response to varying climatic conditions.

Citation: Ballantyne, A. P., P. A. Baker, S. C. Fritz, and B. Poulter (2011), Climate-mediated nitrogen and carbon dynamics in a tropical watershed, J. Geophys. Res., 116, G02013, doi:10.1029/2010JG001496.

\section{Introduction}

[2] A central challenge to Earth system science is to understand the potential feedbacks between climate variability and the biogeochemical cycles of specific elements important to biological productivity. Although many studies have identified changes in ecosystem function in response to climate variability at annual to decadal scales [Goulden et al., 1996; O'Reilly et al., 2003; Stapp et al., 1999], fewer studies consider changes in ecosystem function over centennial to millennial timescales. Thus it is difficult to determine the long-term response and resilience of ecosystems to climate variability. One approach that may provide critical insight into the long-term response of ecosystem function to future climate change is to investigate how the biosphere has responded to past climate variability [Clark et al., 2001].

\footnotetext{
${ }^{1}$ Nicholas School of the Environment, Duke University, Durham, North Carolina, USA.

${ }^{2}$ Now at Department of Geological Sciences, University of Colorado at Boulder, Boulder, Colorado, USA.

${ }^{3}$ Department of Geosciences and School of Biological Sciences, University of Nebraska, Lincoln, Nebraska, USA.

${ }^{4}$ Now at Land Use Dynamics, Swiss Federal Research Institute WSL, Birmensdorf, Switzerland.

Copyright 2011 by the American Geophysical Union. 0148-0227/11/2010JG001496
}

[3] Lakes provide an excellent context for studying the response of the biosphere to climate forcing, because they integrate both climatic and biotic processes occurring in their watersheds over a range of timescales [Cohen, 2003]. Furthermore, aquatic ecosystems may undergo sudden shifts in ecological state due to climatic perturbations that affect nutrient availability and in turn biological productivity [Scheffer et al., 2001]. For instance, the ice-free season has been extended by approximately 12 days over the last 100 years for many temperate lakes due to increasing global temperatures [Magnuson et al., 2000]. This decrease in lake ice has resulted in an increase in primary productivity in some high-latitude lakes due to an increase in light penetration and nutrient availability [Quayle et al., 2002]. In contrast, some tropical lakes have become more thermally stratified in response to increased warming [Verburg et al., 2003] resulting in a decrease in nutrient availability and ultimately a reduction in primary productivity [O'Reilly et al., 2003]. Moreover, lakes are very sensitive to the hydrologic balance within watersheds, and changes in regional precipitation and evaporation in response to global climate change also may affect nutrient supply, which in turn may impact primary productivity [Kropelin et al., 2008]. Although lakes are clearly sensitive indicators of climate change, their biogeochemical response may vary depending upon regional climate forcing. 


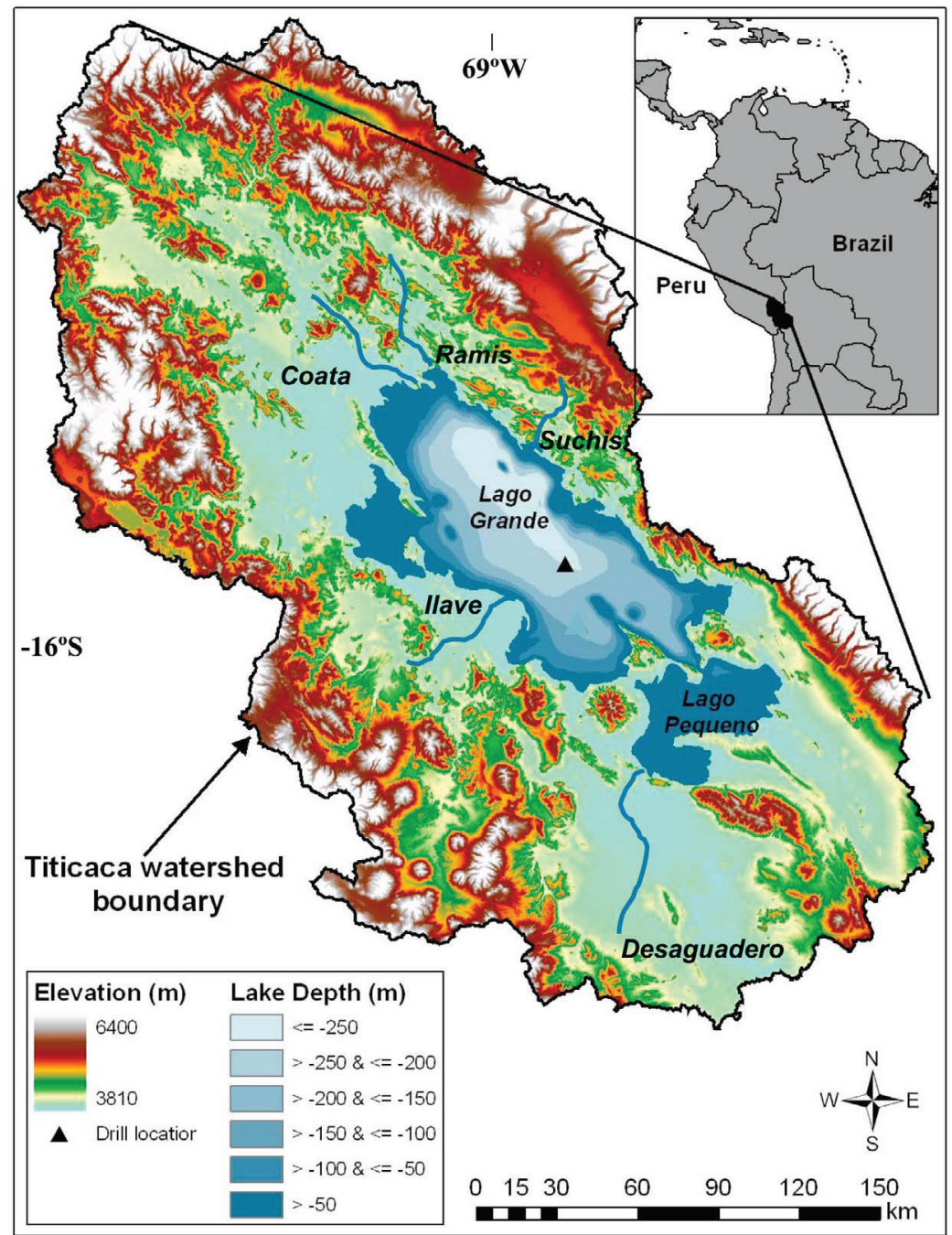

Figure 1. Digital elevation model of the Lake Titicaca catchment. Bathymetric map was digitized and merged with satellite-derived topography data for the watershed. The major rivers flowing into the lake (i.e., Ramis, Coata, Suchis, and Ilave) drain into Lago Grande, and the only outflow (Desaguadero) drains from Lago Pequeno. Inset shows location of the Lake Titicaca watershed in the Altiplano of South America.

[4] In contrast to most temperate lakes, in which primary productivity is limited by phosphorus availability [Schindler, 1977], primary productivity in tropical lakes is often limited by nitrogen availability [Lewis, 2002]. It has been proposed that nitrogen limitation is prevalent in tropical lakes due to prolonged seasonal stratification, which leads to anoxic conditions that promote denitrification [Lewis, 2002]. However, it is uncertain whether this nitrogen-limited state is stable for tropical lakes or whether climate variability can cause shifts in nitrogen cycling that may result in changes in lake trophic state.

[5] To better understand how climate variability may affect nitrogen cycling in tropical watersheds, we investigated changes in the biogeochemical properties measured in a long sedimentary record obtained from Lake Titicaca spanning the last 350,000 years. We first reconstruct lake level in response to climate variability and then we explore how climate variability has altered the nitrogen cycle and primary productivity in this large tropical watershed.

\section{Site Description and Methods}

\subsection{Hydrology and Limnology}

[6] Lake Titicaca $\left(16^{\circ} \mathrm{S}, 69^{\circ} \mathrm{W} ; 3810 \mathrm{~m}\right.$ asl) is a large tropical lake located on the Altiplano between Bolivia and Peru (Figure 1). There are four rivers flowing into Lake Titicaca, the Rio Suchis, Rio Ramis, Rio Coata, and Rio Ilave, and the lake has one outflow, the Rio Desaguadero. The channel depth of the Rio Disaguadero sits $10 \mathrm{~m}$ below modern lake level; therefore, as lake level drops below $3800 \mathrm{~m}$ asl, Lake Titicaca becomes an endorheic basin. Hereafter we refer to lake levels greater than $3800 \mathrm{~m}$ asl as lake "high-stands" and lake levels below $3800 \mathrm{~m}$ asl as lake "low-stands." Presently, Lake Titicaca is monomictic with 
Table 1. Modern Nitrogen Budget of Lake Titicaca

\begin{tabular}{|c|c|c|}
\hline & Nitrogen & Source \\
\hline \multicolumn{3}{|l|}{ Inputs } \\
\hline $\mathrm{N}$ fixation $\left(\mathrm{mg} \mathrm{m}^{-2} \mathrm{yr}^{-1}\right)$ & 1508 & Wurtsbaugh et al. [1992] \\
\hline Wet deposition $\left(\mathrm{mg} \mathrm{m}^{-2} \mathrm{yr}^{-1}\right)$ & 211 & Holland et al. [1999] \\
\hline Dry deposition ( $\left.\mathrm{mg} \mathrm{m}^{-2} \mathrm{yr}^{-1}\right)$ & 212 & Holland et al. [1999] \\
\hline Riverine $\left(\mathrm{mg} \mathrm{m}^{-2} \mathrm{yr}^{-1}\right)$ & 110 & Vincent et al. [1984] \\
\hline \multicolumn{3}{|l|}{ Outputs } \\
\hline Sedimentation $\left(\mathrm{mg} \mathrm{m}^{-2} \mathrm{yr}^{-1}\right)$ & 1336 & mean value from this study \\
\hline Riverine $\left(\mathrm{mg} \mathrm{m}^{-2} \mathrm{yr}^{-1}\right)$ & 513 & $\begin{array}{l}\text { calculated as the difference } \\
\text { between inputs and outputs }\end{array}$ \\
\hline $\begin{array}{l}\text { Water column denitrification } \\
\left(\mathrm{mg} \mathrm{m}^{-2} \mathrm{yr}^{-1}\right)\end{array}$ & 150 & Vincent et al. [1984] \\
\hline $\begin{array}{l}\text { Sediment denitrification } \\
\quad\left(\mathrm{mg} \mathrm{m}^{-2} \mathrm{yr}^{-1}\right)\end{array}$ & 42 & Vincent et al. [1984] \\
\hline
\end{tabular}

seasonal mixing of the water column during the austral summer, which replenishes nutrients to surface waters. Because of its high altitude, Lake Titicaca has low dissolved oxygen concentrations, and hypolimnetic waters tend to become anoxic during the austral winter [Vincent et al., 1985]. Lake Titicaca is oligosaline $\left(1 \mathrm{~g} \mathrm{~L}^{-1}\right)$ and has extremely low concentrations of nitrate $\left(2.5-3.5 \mu \mathrm{g} \mathrm{L}^{-1}\right)$ and phosphate (3-24 $\mathrm{g} \mathrm{L}^{-1}$ ) in surface waters [Vincent et al., 1984] resulting in very low primary productivity [Richerson et al., 1975]. This reduced N:P molar ratio is well below the Redfield Ratio (16:1 molar ratio) resulting in persistent nitrogen limitation of primary productivity, despite the often abundant nitrogen-fixing cyanobacteria. [Vincent et al., 1984]. Inputs to Lake Titicaca's nitrogen budget are dominated by $\mathrm{N}$ fixation, and the dominant form of nitrogen removal is through sedimentation (Table 1).

\subsection{Lake Sediment Sampling}

[7] In May 2001, parallel holes were drilled at three locations within the Lake Titicaca basin using the DOSECC (http://www.dosecc.org/) GLAD800 platform equipped with hydraulic and rotary coring devices. Here we report the findings from the longest core LT01-2B, which was $136 \mathrm{~m}$ in total sediment thickness obtained from a water depth of $235 \mathrm{~m}$ [Fritz et al., 2007]. This continuous core was sampled at $10 \mathrm{~cm}$ intervals during glacial periods and $2 \mathrm{~cm}$ intervals during interglacial periods for biogeochemical properties, and continuously at $20 \mathrm{~cm}$ intervals for the identification and enumeration of diatoms, as well as biogenic silica measurements. These analyses included 1705 measurements of $\mathrm{CaCO} 3,1695$ isotopic measurements, 664 diatom counts, and 828 biogenic silica measurements throughout the core.

\subsection{Estimating Age-Depth Relationship of Sediment Core}

[8] The chronology of this core was established by a combination of (1) radiocarbon dating using $19{ }^{14} \mathrm{C}$ dates from acid-leached bulk fractions obtained from upper sedimentary layers, (2) U/Th dating of the aragonite fraction of sediments deposited during the last interglacial, and (3) tuning peak carbonate concentrations during interglacials with maxima in $\mathrm{CO}_{2}$ concentrations measured in the Vostok ice core [Petit et al., 1999]. For actual radionuclide dates and a more detailed description of the age model, see Fritz et al. [2007].

[9] In order to calculate sediment accumulation rate, a spline function was fit to the age-depth relationship (Figure 2a), and the first derivative of this spline function was calculated to estimate changes in sedimentation rate $\left(\mathrm{m} \mathrm{yr}^{-1}\right)$. Changes in sedimentation rate derived from this spline function were less abrupt and less variable than changes in sedimentation rate derived from a simple linear interpolation scheme (Figure 2b). Therefore, in the absence of additional dates, we feel that this is the most conservative age model for calculating changes in sedimentation rate. Sediment density $\left(\mathrm{g} \mathrm{cm}^{-3}\right)$ was measured using a Geotek standard multisensor core logger (Figure 2c) at LacCore (University of Minnesota, USA). Last, sediment accumulation rate $\left(\mathrm{g} \mathrm{m}^{-2} \mathrm{yr}^{-1}\right)$ was calculated as the product of sedimentation rate and sediment density. Based on this approach, it is apparent that changes in sediment accumulation rate are very sensitive to changes in density (Figure $2 \mathrm{~d}$ ).

\subsection{Biogeochemical Analyses and Lake-Level Proxies}

[10] Sediment samples were analyzed for total weight $\%$ $\mathrm{CaCO}_{3}$ and total \% organic carbon, nitrogen, and their respective isotopic ratios. Sediment samples were also analyzed for \% biogenic silica and diatoms. Samples were dissolved in buffered acetic acid, allowing for the measurement of $\mathrm{CaCO}_{3}$ in solution using a Perkin Elmer Model \#5000 atomic absorption spectrophotometer ( $\sigma=0.16 \%$ dry wt.). The supernatant was then decanted, and the insoluble organic fraction was rinsed several times in deionized water and was dried at $60^{\circ} \mathrm{C}$. Dried sediments were weighed into tin capsules for the analysis of total carbon and nitrogen, as well as the isotopic ratios of carbon and nitrogen. Carbon and nitrogen were measured using a Carlo Erba Elemental Analyzer. Combusted samples were then conveyed by a helium carrier gas to a Finnegan MAT (Delta Plus XL) continuous flow mass spectrometer where individual isotopes were separated by mass $(\sigma=0.2 \%)$. All isotopic data are reported as $\delta$ values defined as $\delta=\left(R / R_{s t}-1\right) \times 1000$ where $R$ is the ratio of isotopes in the sample and $R_{s t}$ is the ratio of isotopes in the standard. For carbon isotopes $\left(\delta^{13} \mathrm{C}\right)$ all values are reported with respect to the Vienna Pee Dee Belemnite (VPDB) standard $\left(R_{s t}=1.12372 \times 10^{-2}\right)$ and for nitrogen isotopes $\left(\delta^{15} \mathrm{~N}\right)$ all values are reported with respect to the atmospheric $\mathrm{N}_{2}$ standard $\left(R_{s t}=3.68 \times 10^{-3}\right)$. Biogenic silica concentrations were measured spectrophotometrically after a $1 \mathrm{~h} \mathrm{Na} \mathrm{Na}_{2} \mathrm{CO}_{3}$ extraction, following the methodology of DeMaster [1979]. Prior analysis of sediments spanning the length of the core using a $1-5 \mathrm{~h}$ time-course extraction determined that the extraction of biogenic silica was complete within $1 \mathrm{~h}(\sigma=1-2 \%)$. For diatom analysis, samples were treated with $\mathrm{HCl}$ to remove carbonate and $\mathrm{H}_{2} \mathrm{O}_{2}$ to remove organic matter. Quantitative estimates of diatom abundance were made by adding polystyrene microspheres to the solution and mounting the solution on glass slides. Diatom species were enumerated at 1000x magnification using differential interference contrast, and taxa were characterized as planktonic, benthic or saline based on contemporary calibrations to modern environments [Tapia et al., 2003].

[11] Several proxies for inferring changes in lake level have been developed and validated for the Lake Titicaca 


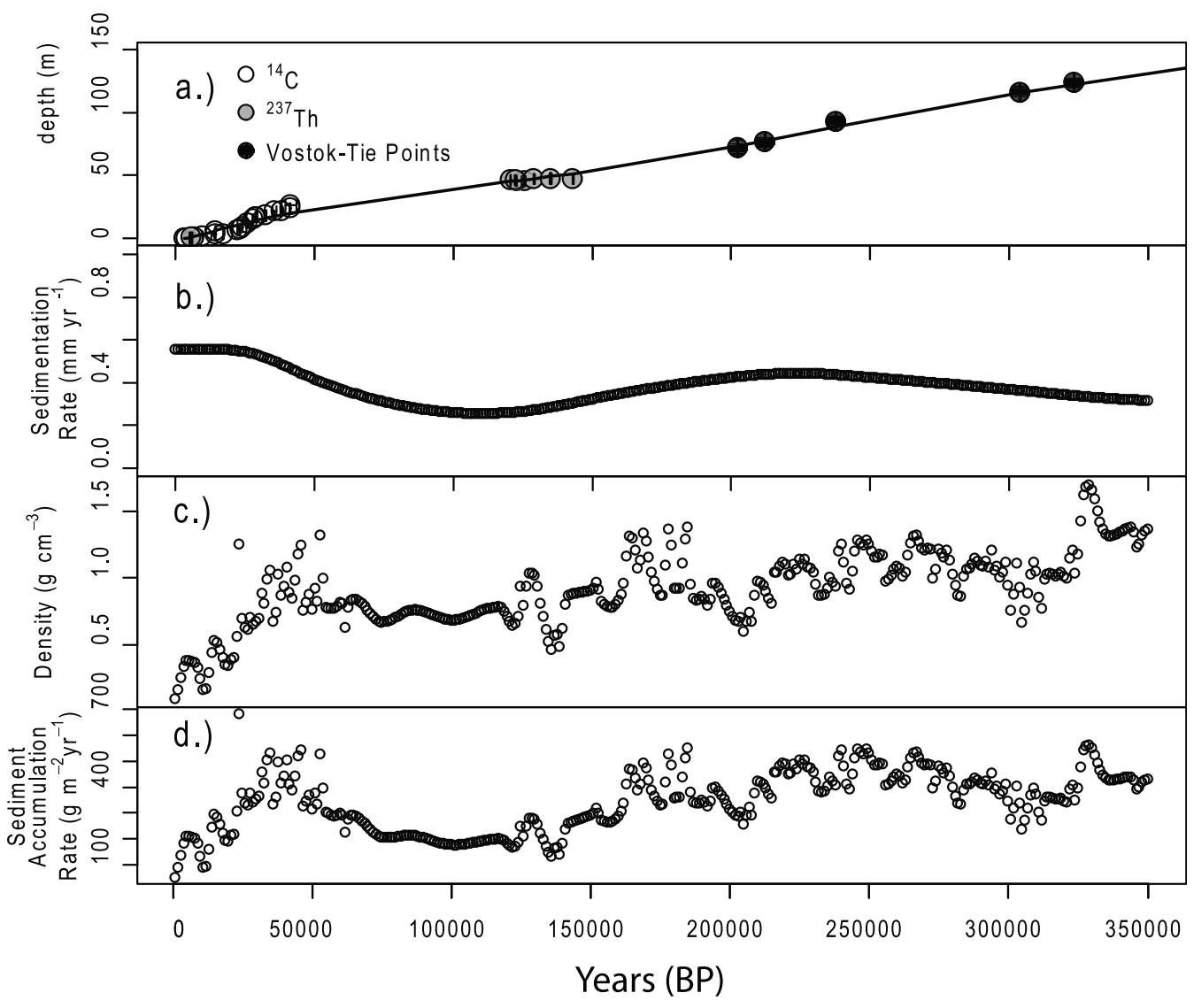

Figure 2. Age model and changes in sedimentation accumulation rate for Lake Titicaca over the past 350,000 years. (a) Ages estimated from carbon 14 and thorium 237 dates, as well as correspondence with the Vostok ice core. Error bars associated with individual dates are plotted and are reported in Table 1. For a description of the age-depth model, see Fritz et al. [2007]. (b) A smooth spline was fit to the relationship between age and depth to estimate changes in sedimentation rate. Sedimentation rates were calculated as the first derivative of the spline function (in Figure 2a) at 1,000 year time steps. (c) Density values have been interpolated to a 1,000 year time step and plotted as a function of time, and (d) changes in sediment accumulation rate are calculated.

basin [Baker et al., 2001; Cross et al., 2000; Rowe et al., 2003; Tapia et al., 2003]. These proxies, including carbon isotopic ratio of organic sediments $\left(\delta^{13} \mathrm{C}\right)$, weight percentage of calcite $\left(\mathrm{CaCO}_{3}\right)$, and changes in diatom assemblage, capture most of the temporal variability in lake level over time. When the level of Lake Titicaca drops below its outflow calcite concentrations increase, begin to precipitate, and settle from the water column [Baker et al., 2001]. The second lake level proxy employed in this study is the $\delta^{13} \mathrm{C}$ of organic sediments. Algae tend to have a bimodal distribution of carbon isotopic values, with planktonic algae generally more depleted $\left(\delta^{13} \mathrm{C}=-28 \%\right)$ and benthic algae and littoral macrophytes more enriched $\left(\delta^{13} \mathrm{C}=-10 \%\right)$ [France, 1995]. Thus an increase in $\delta^{13} \mathrm{C}$ of organic sediments reflects expanded productivity from littoral areas resulting from a decline in lake level. Although primary productivity may also influence $\delta^{13} \mathrm{C}$ values in the organic fraction of sediments [Brenner et al., 1999], the effectiveness of this lake level proxy has been validated by measuring the carbon isotopic values of modern aquatic plant material and samples from the surface sediments over a range of depths [Cross et al., 2000; Rowe et al., 2003; Seltzer et al., 2002]. Furthermore, decreases in lake level tend to be temporally covariant with increases in primary productivity on shorter timescales [Baker et al., 2001], and both of these processes result in more enriched $\delta^{13} \mathrm{C}$ values. The third proxy of lake level is based on the affinities of diatom assemblages to benthic, saline or planktonic environments [Tapia et al., 2003]. As lake level drops below the outflow and salinity increases a greater proportion of both benthic and saline diatoms is observed, whereas when lake level increases a relative increase in the proportion of planktonic diatoms is observed [Baker et al., 2001].

[12] To derive a single curve of lake-level changes for Lake Titicaca, temporal covariance from independent proxies were combined using principal components analysis. All lake level proxy data were interpolated to a common timescale of 1,000 year intervals using a piecewise cubic spline. Interpolated proxy data were then log transformed and normalized to their respective mean and standard deviation values prior to principal components analysis. All statistical 


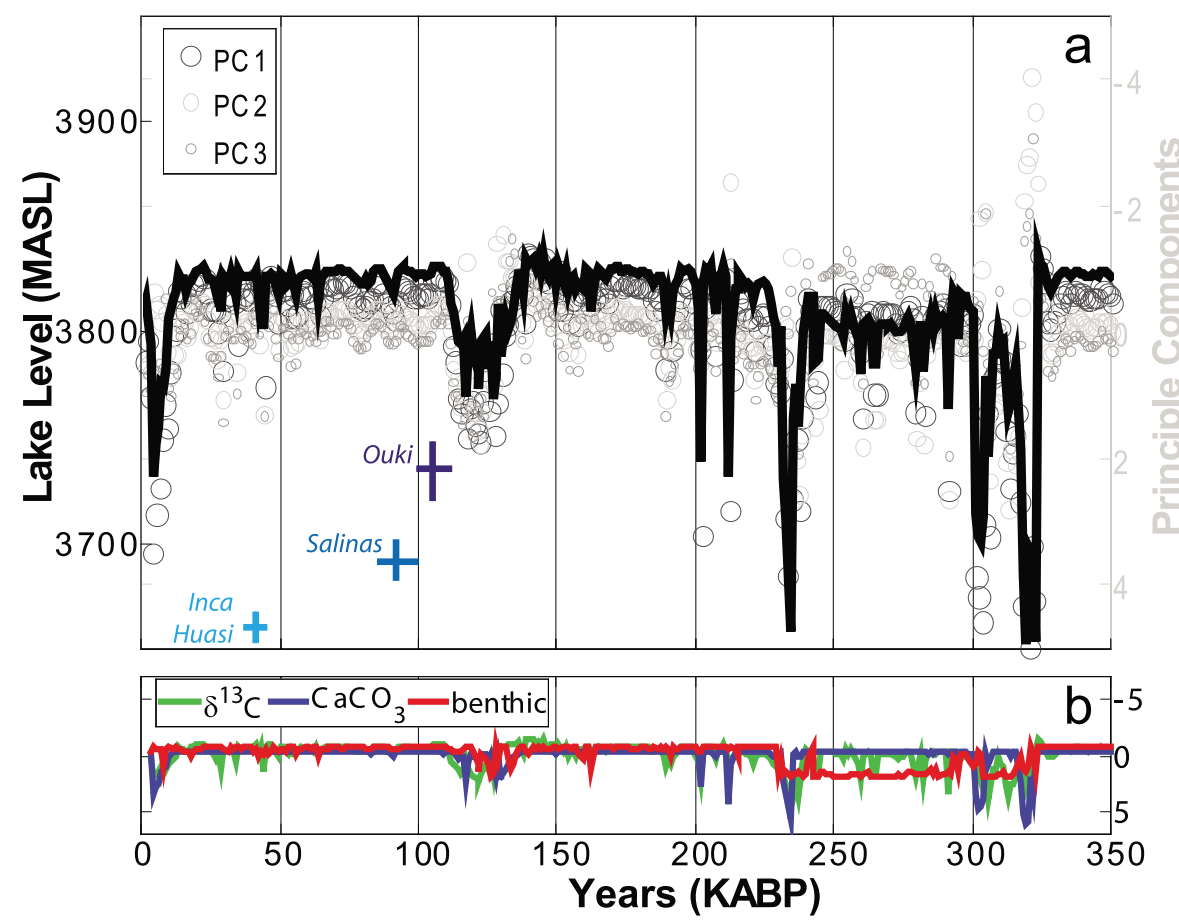

Figure 3. Changes in the level of Lake Titicaca during the late Pleistocene inferred from the principle components of variability in lake level proxies. (a) Changes in lake level, plotted as meters above sea level ( $\mathrm{m}$ asl), have been scaled to seismic data. The first three principle components of lake level variability derived from biogeochemical proxies of lake sediments are plotted by size according to the amount of variance explained (PC1, 59\%; PC2, 26\%; PC3, 15\%). Also plotted for comparison are lake highstand records for paleolakes Inca Huasi, Salinas, and Ouki from Placzek et al. [2006]. (b) The biogeochemical proxies of lake level in the sediments of Lake Titicaca included in this analysis are organic carbon isotopes $\left(\delta^{13} \mathrm{C}\right.$, green), calcite $\left(\mathrm{CaCO}_{3}\right.$, blue), and benthic diatoms (benthic, red). Proxy data have been normalized and are plotted as deviations from zero. All data have been interpolated to 1,000 year intervals and are plotted as kiloannum before present (KABP).

analyses were performed using $\mathrm{R}[R$ Development Core Team, 2007].

\section{Results}

\subsection{Climate Variability Inferred From Lake-Level Proxies}

[13] All three of our lake level proxies revealed a coherent response to climate variability over time (Figure 3b). All three proxies contributed negative loadings to principal component one, with $\delta{ }^{13} \mathrm{C}$ contributing the most loading to principal component one (Table 2). Based on these principal components we derived a novel approach for combining this shared variance into a single lake-level curve for Lake Titicaca during the late Quaternary period. The first principal component ( $p c 1)$ explained 59\% of the variance, the second principal component ( $p c 2$ ) explained $26 \%$ of the variance, and the third principal component $(p c 3)$ explained $15 \%$ of the variance. Thus the scores from each principal component were extracted, weighted by the amount of variance explained and combined by depth to create the following composite lake level curve:

$$
\Delta L=L-[p c 1(.59)+p c 2(.26)-p c 3(.15)] \times S
$$

where the sign of each principal component is determined by the net loading of each proxy on that component. To estimate actual changes in lake-level $(\Delta L)$ in terms of meters above sea level ( $\mathrm{m}$ asl), principal components were subtracted from modern lake level $(L)$, which is approximately $3810 \mathrm{~m}$ asl and then scaled by $S=38.1$ to fit the midHolocene low-stand of $3725 \mathrm{~m}$ asl, previously identified in seismic reflectivity profiles of Lake Titicaca [D'Agostino et al., 2002; Seltzer et al., 1998]. Although each one of these proxies may have its faults, this approach allowed us to combine the temporal covariance shared between proxies to derive a continuous quantitative lake curve (Figure 3a).

Table 2. Principal Components Analysis of Variability in LakeLevel Proxies With Depth ${ }^{\mathrm{a}}$

\begin{tabular}{lccc}
\hline \multicolumn{1}{c}{ Proxy } & $\begin{array}{c}\text { Principal } \\
\text { Component } 1\end{array}$ & $\begin{array}{c}\text { Principal } \\
\text { Component } 2\end{array}$ & $\begin{array}{c}\text { Principal } \\
\text { Component 3 }\end{array}$ \\
\hline Benthic diatoms & -0.56 & 0.64 & 0.53 \\
Calcium carbonate & -0.52 & -0.76 & 0.38 \\
$\delta^{13}$ C organic & -0.64 & - & -0.76 \\
Percent variance explained & $59 \%$ & $26 \%$ & $15 \%$ \\
\hline
\end{tabular}

\footnotetext{
${ }^{\mathrm{a}}$ Reported are the loadings of each proxy on each successive principal
} component and the overall variance explained by each principal component. 


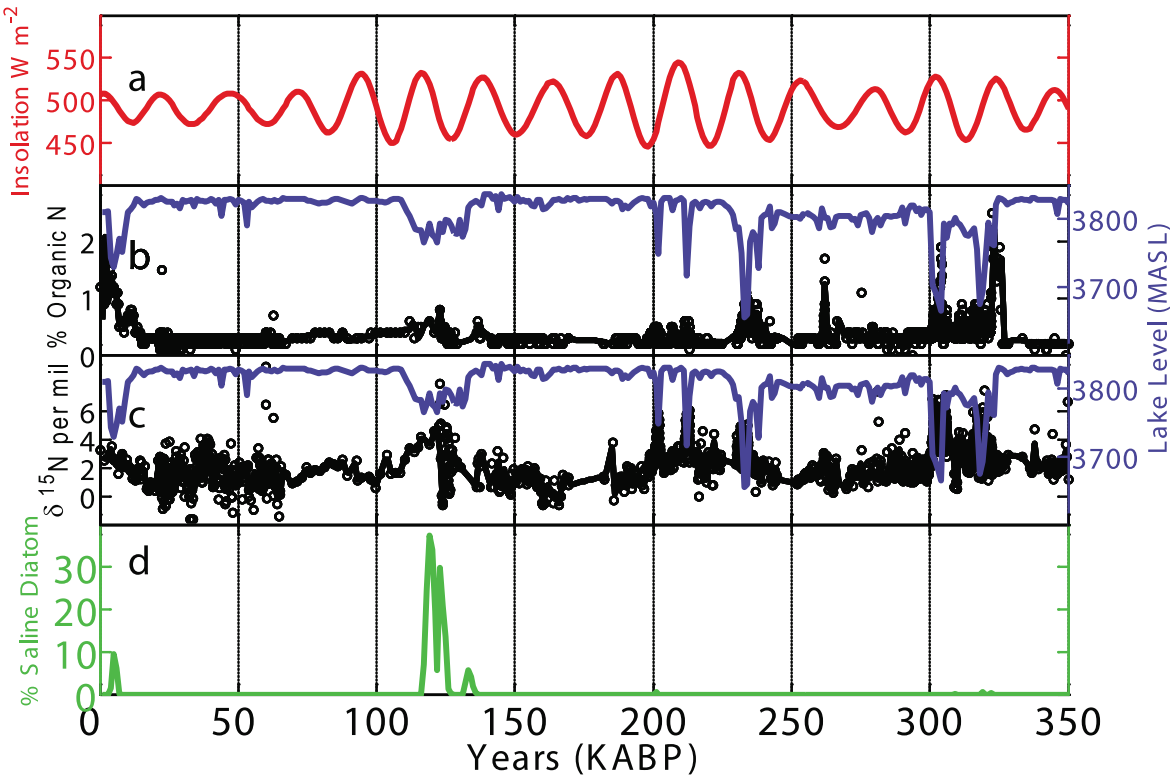

Figure 4. Changes in nitrogen dynamics in response to changes in lake level of Lake Titicaca. (b) Peaks in the percentage of organic nitrogen correspond with inferred periods of low lake level (blue). (c) Peaks in the isotopic signature $\left(\delta^{15} \mathrm{~N}\right)$ of organic nitrogen also correspond to lower lake levels (blue). Plotted for comparison are the main drivers of density stratification in Lake Titicaca: (a) changes in December insolation from Berger and Loutre [1991] for $15^{\circ} \mathrm{S}$ and (d) changes in the relative proportion of saline diatoms within the sediments of Lake Titicaca. All data (open circles) have been linearly interpolated to 1,000 year intervals (black lines) and plotted as kiloannum before present (KABP).

[14] Proxy measurements of lake sediments revealed four discrete intervals over the past 350,000 years in which Lake Titicaca level dropped significantly (Figure 3 ). These intervals were associated with glacial-interglacial cycles, such that prolonged glacial periods were characterized by high lake levels, whereas interglacial intervals were characterized by abrupt drops in lake level between 40 and $160 \mathrm{~m}$ [Fritz et al., 2007].

[15] These results are consistent with previous observations spanning the last 25,000 years indicating that glacial periods are wetter than interglacial periods in the Altiplano region of tropical South America [Baker et al., 2001]. These results are also corroborated by paleo-shorelines from the southern Altiplano dated to be between 30,000 and 110,000 years old (Figure 3) that indicate large paleo-lakes in the southern Altiplano and generally wetter conditions during the last glacial interval [Placzek et al., 2006].

\subsection{Response of Nitrogen Cycle to Climate Variability}

[16] Changes in lake level in response to climate variability have dramatically altered the availability and cycling of nitrogen in Lake Titicaca (Figure 4). Alterations to the nitrogen cycle are most evident when lake levels dropped during interglacials and sediment nitrogen content increased by a factor of 4-8. These increases in nitrogen content during interglacial low-stands are accompanied by a factor 2-5 increase in isotopic enrichment of nitrogen in the organic fraction of Lake Titicaca sediments (Figure 4c). These increases in $\mathrm{N}$ availability are also reflected in $\mathrm{N}$ accumulation rates; although, somewhat attenuated due to decreases in sediment density in contemporary sediments (Figure S1, available as auxiliary material). ${ }^{1}$

[17] These changes in $\mathrm{N}$ isotopes are probably the result of changes in the isotopic composition of organic source material [Watanabe et al., 2004], changes in nitrogen cycling within the water column [Altabet and Francois, 1994], or changes in diagenesis [Lehmann et al., 2002]. Decreases in lake level during interglacial intervals are certainly suggestive of increased allochtonous inputs from the watershed that may have had different $\mathrm{N}$ isotopic signatures. Increases in solar insolation at this latitude during interglacials (Figure 4a) may have contributed to increased thermal stratification resulting in the decreased oxygen levels required for denitrification. Similarly, evidence of increased salinity, at least during the last two interglacial intervals (Figure 4d), would suggest increased density stratification as well that may have promoted denitrification.

[18] The observed correspondence between the climatedriven changes in lake level and nitrogen concentration in Lake Titicaca is verified by investigating the variability in the frequency domain. Both lake level and nitrogen variability show a dominant 100,000 (i.e., 350,000/3.5) frequency over the course of our record associated with global glacial cycles (Figure 6a). The cross-wavelet transform also shows significant coherence in frequency between lake level and $\mathrm{N}$ concentration at approximately 10,000, 125,000,

${ }^{1}$ Auxiliary materials are available in the HTML. doi:10.1029/ 2010JG001496. 


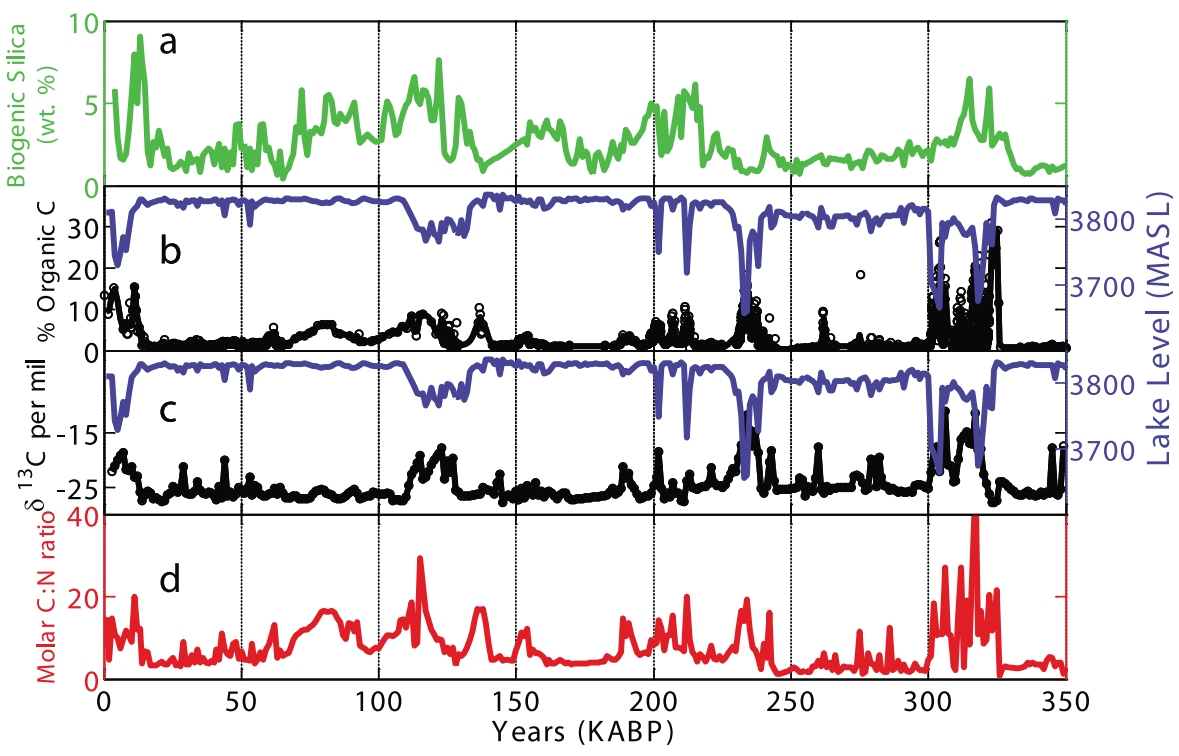

Figure 5. Changes in carbon dynamics in response to changes in lake level of Lake Titicaca. (b) Peaks in the percentage of organic carbon correspond with inferred periods of low lake level (blue). (c) More enriched isotopic values of organic $\mathrm{C}\left(\delta^{13} \mathrm{C}\right)$ correspond with lower lake levels (blue). (a) Plotted for comparison is the weight percent biogenic silica indicating an increase in diatom productivity during interglacial low-stands. (d) Also plotted is the molar C:N ratio indicating an increase in the relative amount of $\mathrm{C}$ to $\mathrm{N}$ in sediments during interglacial low-stands. All data (open circles) have been linearly interpolated to 1,000 year intervals (solid black lines) and plotted as kiloannum before present (KABP).

225,000, and 325,000 years before present (Figure 1a). Thus we can say with confidence that the four prominent drops in lake level observed during the Pleistocene have all been associated with an increase in $\mathrm{N}$ concentration.

\subsection{Response of Carbon Cycle to Climate Variability}

[19] The concentration of organic carbon also increased during interglacial low-stands by a factor of 5-30 (Figure 5) as did $\mathrm{C}$ accumulation rates (Figure S2). The correspondence between $\mathrm{N}$ and $\mathrm{C}$ content in Lake Titicaca sediments strongly suggests that increased $\mathrm{N}$ availability lead to increased primary productivity during interglacial periods (Figure 5b). However, the observed increases in $\mathrm{C}$ accumulation may also be due to a shift from lake-derived autochtonous carbon sources to terrestrially derived allochtonous sources. Although increases in biogenic silica during interglacial intervals provide an independent proxy of increased autochtonous primary productivity during interglacial intervals (Figure 5a), increases in molar C:N ratios in the organic fraction of sediments are consistent with an increase in terrestrial or littoral vegetation sources (Figure 5d), which tend to have more structural carbon than pelagic algae [Cross et al., 2000].

[20] The variability in carbon content of Lake Titicaca sediments also shows a dominant 100,000 year frequency corresponding with global glacial cycles (Figure 6b). Although this provides strong evidence that global climate cycles have exerted control on carbon dynamics in this system, only 3 of the 4 prominent lake low-stands, at approximately $10,000,225,000$, and 325,000 years before present, show significant coherence with carbon concentration. It appears that the slight increases in $\mathrm{N}$ availability around 125,000 were insufficient to promote a significant increase in

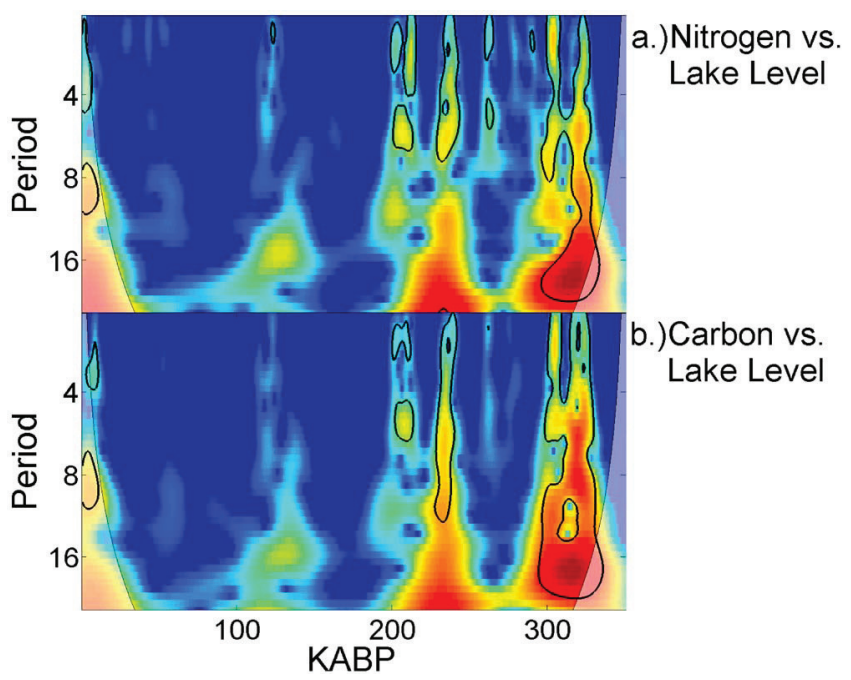

Figure 6. Temporal coherence between changes in lake level and nitrogen concentration as well as carbon concentration. Plotted are the cross-wavelet transforms between (a) \% organic $\mathrm{N}$ and lake level over time, as well as (b) $\%$ organic $\mathrm{C}$ and lake level over time. On the $y$ axes the periods of the dominant peaks occurring in both time series are plotted. The color spectrum indicates the amount of power shared at that period by both time series at that particular time interval, with warmer colors indicating greater coherence. Intervals where decreases in lake level are significantly correlated ( $>95 \%$ confidence) with increases in $\%$ organic $\mathrm{N}$ and $\%$ organic $\mathrm{C}$ are delineated by the solid black line. All data are plotted as kiloannum before present (KABP). 
primary productivity, as evidenced by the diminutive peak in organic $\mathrm{C}$ at this time.

[21] Carbon isotopes in the sediments of Lake Titicaca are also enriched during low-stands, when $\delta^{13} \mathrm{C}$ values tend to increase by $5-10 \%$ (Figure $5 \mathrm{c}$ ). These variations in the $\delta^{13} \mathrm{C}$ of sediment organic matter could be due to changes in the source [Cross et al., 2000; France, 1995], primary production [Brenner et al., 1999], or diagenesis [Lehmann et al., 2002] of organic matter in this system. Littoral plants and benthic algae tend to be more enriched in $\delta^{13} \mathrm{C}$ than pelagic algae in Lake Titicaca [Cross et al., 2000], which is consistent with greater littoral inputs during interglacial low-stands. However, terrestrial C3 plants which are typical in the Titicaca watershed have $\delta^{13} \mathrm{C}$ values of $\sim-28 \%$, which are indistinguishable from $\delta^{13} \mathrm{C}$ values of typical of pelagic algae. Therefore there is no clear isotopic evidence of increased allochtonous inputs, at least from terrestrial plants, during interglacial intervals. Increased isotopic enrichment of the particulate organic carbon pool may also result from decreased isotopic discrimination due to an increase in primary productivity [Brenner et al., 1999; Lehmann et al., 2004; O'Reilly et al., 2003]. Assuming that there have been no major shifts in the $\delta^{13} \mathrm{C}$ of atmospheric $\mathrm{CO}_{2}$ over the Pleistocene, our data indicate a decrease in isotopic discrimination consistent with increased primary productivity during lake low-stands (Figure 5c). This interpretation is consistent with the increase in organic carbon accumulation (Figure S2) and increases in biogenic silica (Figure 5a) during interglacial low-stands. Last, diagenesis may also alter the isotopic composition of organic matter; however, diagenesis is associated with only $1-2 \%$ shifts in $\delta^{13} \mathrm{C}$ [Lehmann et al., 2002] and thus cannot explain the full range of variability in $\delta^{13} \mathrm{C}(-28$ to $-14 \%$ o observed in the sediments of Lake Titicaca over glacial to interglacial cycles. Thus the most parsimonious explanation is that the increased $\mathrm{C}$ content observed during interglacial intervals is the result of increased primary productivity in response to increased $\mathrm{N}$ availability.

\section{Discussion}

\subsection{Climate Factors Influencing the Nitrogen Cycle}

[22] The nitrogen cycle of Lake Titicaca has clearly undergone major shifts in response to global glacial cycles. The increases in nitrogen concentration observed during interglacial low-stands are either the result of an increase in $\mathrm{N}$ supply or a decrease in $\mathrm{N}$ loss from the watershed. Increases in $\mathrm{N}$ deposition may have caused an increase in the supply of $\mathrm{N}$ to Lake Titicaca during interglacial periods. Ice core records from the region suggest increased dust deposition, which would result in an increase in dry $\mathrm{N}$ deposition [Kohfeld and Harrison, 2001]. However, such arid conditions would lead to a reduction in wet $\mathrm{N}$ deposition. These previous results are not necessarily consistent with our results showing an increase in lake levels during glacial period as a result of greater precipitation, which would result in greater wet $\mathrm{N}$ deposition. Thus, although relative changes in wet and dry $\mathrm{N}$ deposition may have occurred over glacial to interglacial cycles, there is no clear evidence that total $\mathrm{N}$ deposition has changed appreciably. However, there is clear evidence that the level of Lake
Titicaca has fluctuated dramatically over the last 350,000 years and that these fluctuations have impacted the nitrogen budget. As lake levels dropped during interglacial periods the lake became a closed basin, thereby eliminating any $\mathrm{N}$ loss from the system due to riverine discharge. Although riverine discharge only accounts for $\sim 25 \%$ of $\mathrm{N}$ loss from the modern nitrogen budget (Table 1); creating a closed system would have lead to the rapid accumulation of $\mathrm{N}$ and would account for the observed increase in $\mathrm{N}$ accumulation rates during interglacials in this system (Figure S1). Thus the observed increase in $\mathrm{N}$ content during interglacials is probably not due to increased $\mathrm{N}$ supply but rather due to reductions in $\mathrm{N}$ loss due to riverine discharge.

[23] The observed changes in $\delta^{15} \mathrm{~N}$ in response to glacial cycles may reflect changes in the relative contribution of $\mathrm{N}$ sources with differing isotopic compositions. Typically, terrestrial plants are more depleted in $\delta^{15} \mathrm{~N}$ and lacustrine phytoplankton are more enriched in $\delta^{15} \mathrm{~N}$ [Watanabe et al., 2004]. This observation holds for the Altiplano region of South America [Abbott et al., 2000], where terrestrial vegetation is more depleted ( $\delta^{15} \mathrm{~N}=1.7 \pm 0.7 \%$ ), aquatic phytoplankton more enriched $\left(\delta^{15} \mathrm{~N}=5.1 \%\right.$ ), and littoral aquatic vegetation is of intermediate value $\left(\delta^{15} \mathrm{~N}=4.6 \pm 0.9 \%\right.$ o) . However, these end-members contradict our observations of variations in $\delta^{15} \mathrm{~N}$ in response to lake level changes. Based on these end-members we would expect $\delta^{15} \mathrm{~N}$ to become more depleted during low lake-stands with greater allochthonous inputs from terrestrial plants, but we actually observe the organic $\mathrm{N}$ fraction becoming more enriched (Figure 4). Therefore changes in $\delta^{15} \mathrm{~N}$ associated with glacial cycles cannot be explained by changes in the source of organic matter contributing to sediments.

[24] Changes in $\delta^{15} \mathrm{~N}$ observed over glacial cycles may also reflect changes in nitrogen cycling within the water column. The relatively depleted values of $\delta^{15} \mathrm{~N}$ characteristic of lake highstands are indicative of an atmospheric $\mathrm{N}_{2}$ source $\left(\delta^{15} \mathrm{~N}=0 \%\right)$. Such an atmospheric source would result from increased $\mathrm{N}$ fixation to compensate for $\mathrm{N}$-limited primary productivity (Figure $4 \mathrm{c}$ ). The observed enrichment in $\delta^{15} \mathrm{~N}$ during interglacial periods may indicate an increase in denitrification that preferentially removes the lighter ${ }^{14} \mathrm{~N}$ isotope. This increase in denitrification is due to anoxic conditions caused by an increase in density stratification and/or an increase in primary productivity. Increased variability in summer insolation at this latitude during interglacial periods [Berger and Loutre, 1991] combined with a decline in lake volume [Fritz et al., 2007] could result in increased thermal stratification. Although there is evidence from diatoms of increased salinity during the last two interglacial intervals (Figure 4d), it is not clear that this increase in salinity was sufficient to cause an increase in density stratification. Instead, we hypothesize that the lakelevel decline actually reduced the stability of thermal stratification and promoted greater water column mixing. This is consistent with an observed increase in primary productivity during interglacial periods (Figure 5). In fact, an increase in stratification cannot be invoked as a mechanism to explain the increase in denitrification because such a scenario would result in a decreased mixing of all nutrients into the photic zone and ultimately a decline in productivity. Thus, we conclude that glacial intervals were characterized 


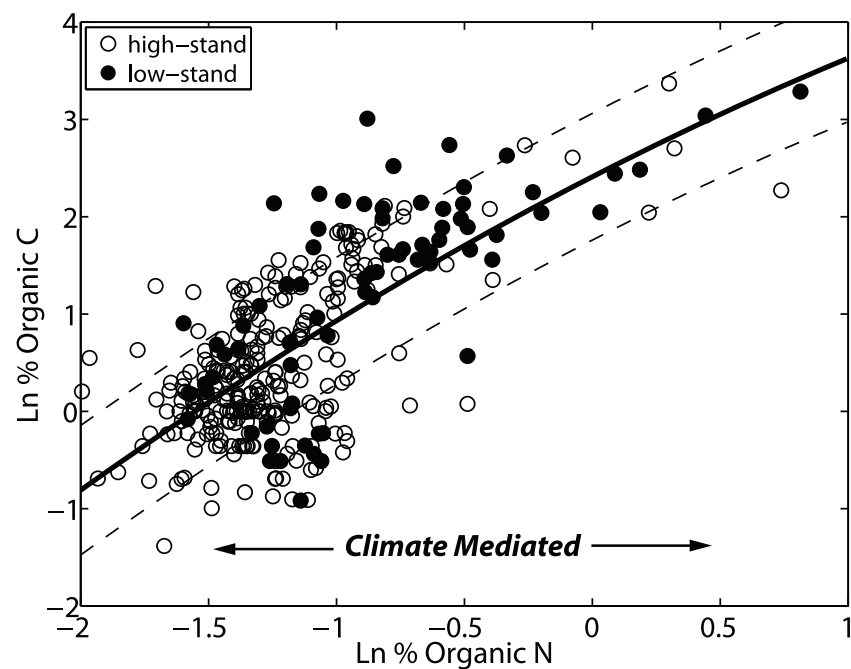

Figure 7. Relationship between nitrogen availability and primary productivity as mediated by climate. Plotted are interpolated values of percent organic $\mathrm{N}$ and organic $\mathrm{C}$ present in the sediments of Lake Titicaca (see Figures 4 and 5). Lake highstands ( $>3800 \mathrm{~m}$ asl, open circles), promoted by wetter regional climate, are characterized by reduced $\mathrm{N}$ availability. Lake low-stands $(<3800 \mathrm{~m}$ asl, solid circles $)$, promoted by drier regional conditions, are characterized by increased $\mathrm{N}$ availability. The significant relationship between $\mathrm{N}$ availability and $\mathrm{C}$ content $(\mathrm{p}$ value $<0.00001 ; \mathrm{R}=0.71$; $\mathrm{DF}=347)$ is optimally described by the second-order polynomial $\operatorname{Ln} \mathrm{C}=-0.1308 \operatorname{Ln} \mathrm{N}^{2}+1.35 \operatorname{Ln} \mathrm{N}+2.41$. All data have been transformed by the natural logarithm (Ln).

by increased $\mathrm{N}$ fixation brought on by decreased $\mathrm{N}$ availability and that interglacial intervals were characterized by increased denitrification brought on by increased $\mathrm{N}$ availability and primary productivity.

[25] Experiments on the effects of diagenesis have revealed a significant depletion in $\delta^{15} \mathrm{~N}$ in particulate organic matter as nitrogen is remineralized under anoxic conditions, but no net effect on isotopic fractionation of nitrogen isotopes under oxic conditions [Lehmann et al., 2002]. Yet, $\delta^{15} \mathrm{~N}$ actually becomes more enriched during interglacial periods when we suspect that increased productivity lead to increased anoxia, suggesting that processes other than diagenesis are affecting the organic nitrogen pool during these periods (Figure 4c). In fact, observations from the sediments of a temperate eutrophic lake suggest that particulate organic matter in the water column is only slightly enriched compared to sedimentary particulate organic matter $(+1.2 \%)$, suggesting only minor diagenetic alteration, even under seasonally anoxic conditions [Lehmann et al., 2002]. Thus the slight isotopic offset between particulate organic matter and sedimentary organic matter caused by diagenesis cannot fully account for the 6\% range of variability observed in the sediments of Lake Titicaca over glacial cycles.

[26] Therefore we have inferred that changes in lake level in response to global glacial cycles have greatly altered the $\mathrm{N}$ cycle in Lake Titicaca. As lake level dropped below its outflow during interglacial intervals, $\mathrm{N}$ concentrations increased in the water column. Although this increase in $\mathrm{N}$ availability probably promoted denitrification in the water column, there was a net accumulation of $\mathrm{N}$ in the system as evidenced by our sedimentary records.

\subsection{Climate Factors Influencing the Carbon Cycle}

[27] Interglacial low-stands in Lake Titicaca are also accompanied by considerable increases in carbon concentration that could be due to increases in allochtonous organic inputs from the watershed or increases in autochtonous inputs due to increased primary productivity. The elevated $\mathrm{C}: \mathrm{N}$ ratios in the organic fraction of sediments during interglacials are indicative of greater contributions from terrestrial vegetation with more structural carbon. Furthermore, the enrichment of $\delta^{13} \mathrm{C}$ during interglacial intervals provides independent evidence for an increase in the contribution of benthic algae and macrophytes that tend to be more isotopically enriched during low-stands. In contrast, the more depleted $\delta^{13} \mathrm{C}$ values during glacial highstands indicate a greater contribution of pelagic algae to lake sediments [France, 1995]. In fact, this is consistent with estimated source values of more isotopically enriched aquatic macrophytes $\left(\delta^{13} \mathrm{C}=-14.8 \%\right)$ and more depleted aquatic algae $\left(\delta^{13} \mathrm{C}=-22.5 \%\right)$ previously analyzed from the Lake Titicaca watershed [Abbott et al., 2000; Cross et al., 2000].

[28] Although increases in organic carbon concentrations can be explained in part by increased allochtonous inputs, there is also evidence that these increases are due to increases in autochtonous inputs as a result of increased primary productivity. First, the increase in $\mathrm{N}$ availability in this $\mathrm{N}$-limited system should promote increases in primary productivity. These increases in primary productivity are corroborated by increases in biogenic silica during interglacial low-stands. Moreover, these increases in carbon concentration coincide with isotopic enrichment of the organic $\delta^{13} \mathrm{C}$ pool. Such isotopic enrichment would result from decreased isotopic discrimination of the dissolved inorganic pool as rates of primary productivity increased. Thus the observed increases in organic $\mathrm{C}$ concentrations during interglacial intervals are probably due in part to increased primary productivity.

[29] Another factor that may have altered the elemental and isotopic composition of the organic fraction of sediments is diagenesis. Laboratory experiments suggest that diagenesis under both anoxic and oxic conditions leads to an isotopic depletion of the particulate organic carbon pool [Lehmann et al., 2002]. These results have been corroborated by in situ observations showing a relatively constant isotopic enrichment of approximately $0.5 \%$ between particulate organic carbon in the water column and sedimentary organic carbon [Lehmann et al., 2002]. This would suggest that the affect of diagenesis on the organic fraction of lake sediments is fairly constant and cannot explain the temporal variability of $\delta^{13} \mathrm{C}$ observed in the sediments of Lake Titicaca (Figure 4c).

[30] Therefore we can conclude that the observed variations in carbon concentration and its isotopic composition in the sediments in Lake Titicaca are in fact due to climate variability and not an artifact of diagenesis. The increases in carbon accumulation and the enrichment of $\delta^{13} \mathrm{C}$ during interglacial periods are primarily due to an increase in autochthonous primary productivity in response to greater 
$\mathrm{N}$ availability and to a lesser extent due to increases in allochthonous terrestrial inputs from the watershed.

\section{Conclusions: Biogeochemical Response of Aquatic Ecosystems to Climate Change}

[31] The results from this study suggest that sudden climatic changes may have important physical impacts on aquatic ecosystems that may alter the biogeochemical cycles of important nutrients and ultimately primary productivity. Lake Titicaca represents a remarkably resilient aquatic ecosystem that has repeatedly shifted between two trophic states in response to global climate change: one a nitrogenlimited oligotrophic state and the other a nitrogen-saturated eutrophic state. We have demonstrated that global climate variability has reduced lake levels and transformed Lake Titicaca into an endorheic basin during the last 4 interglacial intervals. These climate-induced changes in lake level have greatly altered $\mathrm{N}$ availability in the watershed and resulted in significant changes in primary productivity (Figure 7). By studying the resilient behavior of aquatic ecosystems that readily shift between trophic states we may gain valuable insight into early indicators that may signal the transition from one stable state to the other [Scheffer et al., 2009].

[32] Future climate variability may alter the abundance and distribution of freshwater resources as well as the physical properties of aquatic ecosystems. We have identified how climate variability may affect the overall hydrologic budget of aquatic ecosystems, which has important implications for nutrient cycling. Although changes in the thermal budget of aquatic ecosystems and their impacts on biogeochemical cycles have been previously identified [Magnuson et al., 2000; O'Reilly et al., 2003; Verburg et al., 2003], changes in the overall hydrologic budget of aquatic ecosystems in response to regional climate processes may ultimately have a greater impact on biogeochemical cycles [Coe and Foley, 2001].

[33] Aquatic ecosystems are sensitive indicators of global change because they integrate the physical, chemical, and biological processes occurring in their catchments [Cohen, 2003]. Because aquatic ecosystems are so sensitive to global change and because they provide valuable ecosystem services, they have been identified as sentinels of climate change [Williamson et al., 2009]. As we recognize that human activity has altered the physical climate by perturbing important biogeochemical cycles, our attention is now drawn to how the biosphere will respond to such perturbations, especially at the regional scale. Here we have presented a case study of how global climate change has altered important biogeochemical cycles in an aquatic ecosystem. Such observations from natural variability in Earth's past may provide us with valuable insight as to how the biosphere will respond to future anthropogenic changes.

[34] Acknowledgments. This paper is dedicated to the adventurous spirit and inquisitive nature of Geoffrey Seltzer. This project was made possible by the drilling staff at DOSECC and LACCORE, James Broda of Woods Hole Oceanographic Institution, our Bolivian collaborators Gonzalo Mollericon and Gonzalo Salas, and the Autoridad Autónoma del Lago Titicaca. P. Tapia completed the diatom analyses, and L. Stevens did the analysis of biogenic silica. We would also like to thank Jonathan Karr at the Duke Environmental Isotope Laboratory for assistance with sample analysis. This work was funded by NSF (ESH) grants to P.A.B. and S.C.F.

\section{References}

Abbott, M. B., et al. (2000), Holocene hydrological reconstructions from stable isotopes and paleolimnology, Cordillera Real, Bolivia, Quat. Sci. Rev., 19, 1801-1820.

Altabet, M. A., and R. Francois (1994), Sedimentary nitrogen isotopic ratio as a recorder for surface ocean nitrate utilization, Global Biogeochem. Cycles, 8, 103-116.

Baker, P. A., et al. (2001), The history of South American tropical precipitation for the past 25,000 Years, Science, 291, 640-643.

Berger, A., and M. F. Loutre (1991), Insolation values for the climate of the last 10 million years, Quat. Sci. Rev., 10, 297-317.

Brenner, M., et al. (1999), Stable isotope $\left(\delta^{13} \mathrm{C}\right.$ and $\left.\delta^{15} \mathrm{~N}\right)$ signatures of sedimented organic matter as indicators of historic lake trophic state, J. Paleolimnol., 22, 205-221.

Clark, J. S., et al. (2001), Ecological forecasts: An emerging imperative, Science, 293, 657-660.

Coe, M. T., and J. A. Foley (2001), Human and natural impacts on the water resources of the Lake Chad basin, J. Geophys. Res., 106 3349-3356, doi:10.1029/2000JD900587.

Cohen, A. S. (2003), Paleolimnology: The History and Evolution of Lake Systems, Oxford Univ. Press, Oxford, U. K.

Cross, S. L., et al. (2000), A new estimate of the Holocene lowstand level of Lake Titicaca, central Andes, and implications for tropical palaeohydrology, Holocene, 10, 21-32.

D’Agostino, K., et al. (2002), Late-quaternary lowstands of Lake Titicaca: Evidence from high-resolution seismic data, Palaeogeogr. Palaeoclimatol. Palaeoecol., 179, 97-111.

DeMaster, D. J. (1979), The marine budgets of silica and 32Si, Ph.D. thesis, Yale Univ., New Haven, Conn.

France, R. (1995), Differentiation between littoral and pelagic food webs in lakes using stable carbon isotopes, Limnol. Oceanogr., 40, 1310-1313.

Fritz, S. C., et al. (2007), Quaternary glaciation and hydrologic variation in the South American tropics as reconstructed from the Lake Titicaca drilling project, Quat. Res., 68, 410-420.

Goulden, M. L., et al. (1996), Exchange of carbon dioxide by a deciduous forest: Response to interannual climate variability, Science, 271, 1576-1578.

Holland, E. A., F. J. Dentener, B. H. Braswell, and J. M. Sulzman (1999), Contemporary and pre-industrial global reactive nitrogen budgets, Biogeochemistry, 46, 7-43.

Kohfeld, K. E., and S. P. Harrison (2001), DIRTMAP: The geological record of dust, Earth Sci. Rev., 54, 81-114.

Kropelin, S., et al. (2008), Climate-driven ecosystem succession in the Sahara: The past 6000 years, Science, 320, 765-768.

Lehmann, M. F., et al. (2002), Preservation of organic matter and alteration of its carbon and nitrogen isotope composition during simulated and in situ early sedimentary diagenesis, Geochim. Cosmochim. Acta, 66, 3573-3584.

Lehmann, M. F., et al. (2004), Seasonal variation of the $\delta^{13} \mathrm{C}$ and $\delta^{15} \mathrm{~N}$ of particulate and dissolved carbon and nitrogen in Lake Lugano: Constraints on biogeochemical cycling in a eutrophic lake, Limnol. Oceanogr., 49, 415-429.

Lewis, W. M. (2002), Causes for the high frequency of nitrogen limitation in tropical lakes, Verh. Int. Verein. Limnol., 28, 210-213.

Magnuson, J. J., et al. (2000), Historical trends in lake and river ice cover in the Northern Hemisphere, Science, 289, 1743-1746.

O'Reilly, C. M., et al. (2003), Climate changes decreases aquatic ecosystem productivity of Lake Tanganyika, Africa, Nature, 424, 766-768.

Petit, J. R., et al. (1999), Climate and atmospheric history of the past 420,000 years from the Vostok ice core, Antarctica, Nature, 399, 429.

Placzek, C., et al. (2006), Geochronology and stratigraphy of late Pleistocene lake cycles on the southern Bolivian Altiplano: Implications for causes of tropical climate change, Bull. Geol. Soc. Am., 118, 515-532.

Quayle, W. C., et al. (2002), Extreme responses to climate change in Antarctic Lakes, Science, 295, 645

R Development Core Team (2007), R: A language and environment for statistical computing, R Found. for Stat. Comput., Vienna.

Richerson, P. J., et al. (1975), A survey of the physical and chemical limnology of Lake Titicaca, Verh. Int. Verein. Limnol., 19, 1498-1503.

Rowe, H. D., et al. (2003), Late Quaternary lake-level changes constrained by radiocarbon and stable isotope studies on sediment cores from Lake Titicaca, South America, Global Planet. Change, 38, 273-290.

Scheffer, M., et al. (2001), Catastrophic shifts in ecosystems, Nature, 413, 591.

Scheffer, M., et al. (2009), Early warning signals for critical transitions, Nature, 461, 53-59. 
Schindler, D. W. (1977), The evolution of phosphorus limitation in lakes, Science, 195, 260-262.

Seltzer, G. O., et al. (1998), High-resolution seismic reflection profiles from Lake Titicaca, Peru-Bolivia: Evidence for Holocene aridity in the tropical Andes, Geology, 26, 167-170.

Seltzer, G. O., et al. (2002), Early warming of tropical South America at the last glacial-interglacial transition, Science, 296, 1685-1686.

Stapp, P., et al. (1999), Stable isotopes reveal strong marine and El Nino effects on island food webs, Nature, 401, 467-469.

Tapia, P. M., et al. (2003), A late quaternary diatom record of tropical climatic history from Lake Titicaca (Peru and Bolivia), Palaeogeogr. Palaeoclimatol. Palaeoecol., 194, 139-164.

Verburg, P., et al. (2003), Ecological consequences of a century of warming in Lake Tanganyika, Science, 301, 505-507.

Vincent, W. F., et al. (1984), Seasonal dynamics of nutrient limitation in a tropical high-altitude lake (Lake Titicaca, Peru-Bolivia): Application of physiological bioassays, Limnol. Oceanogr., 29, 540-552.

Vincent, W. F., et al. (1985), Nitrate cycling in Lake Titicaca (Peru-Bolivia) The effects of high-altitude and tropicality, Freshwater Biol., 15, 31-42.
Watanabe, T., et al. (2004), Biological and environmental changes in Lake Baikal during the late Quaternary inferred from carbon, nitrogen and sulfur isotopes, Earth Planet. Sci. Lett., 222, 285-299.

Williamson, C. E., et al. (2009), Climate change: Sentinels of change, Science, 323, 887-888.

Wurtsbaugh, W. A., W. F. Vincent, and P. J. Richerson (1992), Nitrogen cycling and primary productivity in Lake Titicaca, in Lake Titicaca: $A$ Synthesis of Limnological Knowledge, edited by C. Dejoux and A. Iltis, pp. 120-125, Kluwer, Dordrecht, Netherlands.

P. A. Baker, Nicholas School of the Environment, Duke University, Box 90229, Durham, NC 27708, USA.

A. P. Ballantyne, Department of Geological Sciences, University of Colorado at Boulder, Campus Box 399, 2200 Colorado Ave., Boulder, CO 80309-0399, USA. (ashley.ballantyne@colorado.edu)

S. C. Fritz, Department of Geosciences, University of Nebraska, Box 880340, Lincoln, NE 68588-0340, USA.

B. Poulter, Land Use Dynamics, Swiss Federal Research Institute WSL, CH-8903 Birmensdorf, Switzerland. 